\title{
IMPLEMENTASI MODEL PEMBELAJARAN COOPERATIVE SCRIPT DALAM PERKULIAHAN TEORI \& PRAKTIK PEMBELAJARAN MENYIMAK SEBAGAI UPAYA PENINGKATAN PRESTASI, AKTIVITAS, DAN KETERAMPILAN BERBICARA PADA MAHASISWA SEMESTER 1 PROGRAM STUDI PENDIDIKAN BAHASA DAN SASTRA INDONESIA FKIP UNPAS TAHUN AKADEMIK 2019-2020
}

\author{
Titin Nurhayatin ${ }^{1}$, Rendy Triandy ${ }^{2}$ \\ 1,2PBSI FKIP Universitas Pasundan \\ ${ }^{1}$ titinnurhayatin@unpas.ac.id, ${ }^{2}$ rendytriandy@unpas.ac.id
}

\begin{abstract}
This study aims to determine the effectiveness of the application of cooperative script learning models in lectures Theory \& Practice of Listening Learning as an effort to improve student achievement, activities, and speaking skills. Listening skills are one of the important language skills to be mastered by students, so appropriate strategies or learning models are needed in their application. The research method used in this study is an experimental research method with a pretest-posttest control group design research design. The population in this research were students programme of study in the Indonesian Language and Literature Education FKIP Unpas. The sample in this study was the first semester students Programme of Study in the Indonesian Language and Literature Education FKIP Unpas. Based on the results of data processing using the SPSS 25 application, the value of sig is obtained. (2-tailed) of 0,000 <0.05. This shows that Ha was accepted and Ho was rejected. Therefore, it can be interpreted that the learning outcomes, activities, and speaking skills of semester I students programme of study in the Indonesian Language and Literature Education FKIP Unpas increased in lectures on Theory and Practice of Listening Learning using Cooperative Script learning models.
\end{abstract}

Keywords: Listening Skills, Cooperative Script

\begin{tabular}{l} 
ABSTRAK \\
Penelitian ini bertujuan untuk mengetahui efektifitas penerapan model \\
pembelajaran cooperative script dalam perkuliahan Teori \& Praktik Pembelajaran \\
Menyimak sebagai upaya peningkatan prestasi, aktivitas, dan keterampilan \\
berbicara mahasiswa. Keterampilan menyimak salah satu keterampilan berbahasa \\
yang penting untuk dikuasai mahasiswa, sehinnga dibutuhkan strategi atau model \\
pembelajaran yang tepat dalam penerapannya. Metode penelitian yang digunakan \\
dalam penelitian ini adalah metode penelitian eksperimen dengan desain penelitian \\
pretest-posttest control group design. Populasi dalam penelitian ini adalah \\
mahasiswa Program Studi Pendidikan Bahasa dan Sastra Indonesia FKIP Unpas. \\
Sampel dalam penelitian ini adalah mahasiswa semester I Program Studi \\
Pendidikan Bahasa dan Sastra Indonesia FKIP Unpas. Berdasarakan hasil olah \\
data menggunakan aplikasi SPSS 25 diperoleh nilai sig. (2-tailed) sebesar 0,000 < \\
0,05. Hal tersebut menunjukkan bahwa Ha diterima dan Ho ditolak. Maka dari itu, \\
dapat diartikan bahwa hasil belajar, aktivitas, dan keterampilan berbicara \\
mahasiswa semester I Program Studi Pendidikan Bahasa dan Sastra Indonesia \\
\hline
\end{tabular}


FKIP Unpas meningkat dalam perkuliahan Teori dan Praktik Pembelajaran Menyimak menggunakan model pembelajaran Cooperative Script.

Kata Kunci: Keterampilan Menyimak, Cooperative Script.

\section{A. Pendahuluan}

Peran menyimak dalam kehidupan sehari-hari sangatlah penting, manusia selalu dihadapkan pada berbagai kesibukan menyimak. Apalagi dalam era globalisasi seperti saat ini, sejalan dengan perkembangan ilmu pengetahuan dan teknologi, masyarakat dituntut untuk mampu menyimak berbagai informasi dengan cepat dan tepat, baik secara langsung ataupun dengan berbagai media sosial yang akhir-akhir ini kian menjamur. Keterampilan menyi-mak dan membaca termasuk dalam kategori keterampilan reseptif. Keterampilan reseptif yaitu menerima atau memahami pesan yang disampaikan oleh pembicara atau penulis, sedangkan keterampilan berbica-ra dan keterampilan menulis termasuk dalam kategori keterampilan produktif, yaitu menghasilkan pembicaraan atau tulisan yang efektif.

Keterampilan berbahasa pertama yang dikuasai oleh manusia adalah keterampilan menyimak. Tetapi pada kenyataannya tidak semua orang bisa menguasai keterampilan menyimak dengan baik. Kebanyakan orang hanya menguasai pada tahap mendengarkan saja, belum ke tahap pemahaman ataupun interpretasi. Hal tersebut sejalan dengan pernyataan Tarigan (2008, hlm. 31), "Menyimak adalah suatu proses kegiatan mendengarkan lambang-lambang lisan dengan penuh perhatian, pemahaman, apresiasi, serta interpretasi untuk memperoleh informasi, menangkap isi atau pesan serta memahami makna komunikasi yang telah disampaikan oleh pembicara melalui ujaran atau bahasa lisan."

Empat keterampilan berba-hasa saling berkaitan. Salah satunya hubungan keterampilan menyimak dan keterampilan berbicara. Terdapat hubungan yang era tantara keterampilan menyimak dan berbicara, hubungan ini terdapat pada hal-hal sebagai berikut.

1. "Ujaran(speech) biasanya dipelajari melalui menyimak dan meniru (imitasi). Oleh karena itu model atau contoh yang disimak serta direkam oleh anak sangat penting dalam penguasaan serta kecakapan berbicara. 
2. Kata-kata yang akan dipakai serta dipelajari oleh sang anak biasanya ditentukan oleh perangsang (stimuli) yang ditemuinya dan katakata yang paling banyak memberi bantuan atau pelayanan dalam penyampaian gagasangagasannya.

3. Ujaran sang anak mencer-minkan pemakaian bahasa di rumah dan dalam masyarakat tempatnya hidup. Hal ini terlihat dalam ucapan,intonasi, kosa kata, penggunaan kata-kata, dan pola kalimatnya.

4. Anak yang masih kecil dapat memahami kalimat-kalimat yang jauh lebih panjag dan rumit daripada kalimat yang dapat diucapkannya.

5. Meningkatkan keterampilan menyimak berarti pula membantu meningkatkan kualitas berbicara seseorang.

6. Bunyi suara merupakan faktor penting dalam peningkatan cara pemakaian kata-kata sang anak.

7. Berbicara dengan bantuan alat peraga (visual aids) akan menghasilkan penangkapan informasi yang lebih baik pada pihak penyimak, (Tarigan, 2008, hlm. 3)."

Berdasarkan hal tersebut

diharapkan dengan penguasa-an keterampilan menyimak, mahasiswa bisa meningkatkan keterampilan berbicaranya juga.

Dalam pembelajaran me-nyimak terdapat aneka kendala dalam penerapannya, sehingga membutuhkan model pembe-lajaran yang tepat untuk dapat meningkatkan keterampilan menyimak mahasiswa.
Salah satu model untuk meningkatkan keterampilan menyimak yaitu model pembelajaran kooperatif. "Model pembelajaran kooperatif didefinisikan sebagai penggunaan pembelajaran kelompok kecil sehingga siswa bekerja sama untuk memaksimalkan diri mereka sendiri, berpartisipasi langsung) dan terlibat secara aktif dalam pembelajaran serta belajar bersama satu sama lain untuk mencapai tujuan memecahkan masalah, menyelesaikan tugas atau membuat produk (Adi, Phang, \& Yusof, 2012)." Untuk membantu merencanakan, melaksanakan dan mengelola pembelajaran kelompok kecil, pengajar dapat memilih berbagi macam panduan.

Ada berbagai tipe pembelajaran kooperatif salah satunya yaitu model pembelajaran Cooperative Script. Setiap peserta didik dalam model pembelajaran cooperative script akan diberikan materi ajar secara lengkap. Setelah itu dibagi secara berpasangan dan mereka bergantian secara lisan menyimpulkan materi yang telah diberikan. Kemudian pasangan lainnya mengoreksi benar tidaknya pernyataan yang diungkapkan oleh temannya. 
Didaktik : Jurnal Ilmiah PGSD STKIP Subang, ISSN Cetak : 2477-5673 ISSN Online : 2614-722X Volume V Nomor 2, Desember 2019

"Model

Pembelajaran

Cooperative Script baik diguna-kan dalam pembelajaran

untuk menumbuhkan ide-ide atau gagasan baru (dalam pemecahan suatu permasalahan), daya berfikir kritis serta mengem-bangkan jiwa keberanian dalam menyampaikan halhal baru yang diyakininya benar (Susiloyoga, 2016)." Cooperative Script merupakan suatu cara membuat naskah tulisan tangan secara bekerjasama dengan berpasangan dan bergantian secara lisan dalam mengintisarikan materi-materi yang dipelajari. "Model pembelajaran Cooperative Script ini diadaptasikan dengan kemampuan siswa dalam proses pembelajarannya serta memba-ngun kemampuan siswa untuk membaca dan menyusun rangkuman berdasarkan materi yang dibacanya, sehingga dapat meningkatkan pemahaman konsep siswa terhadap materi yang diajarkan (Natalina, Nursal, \& Srini, 2013)." Dengan model pembelajaran Cooperative Script, masiswa akan terlatih mengem-bangkan ide-idenya dan dapat membantu mahasiswa untuk membiasakan belajar berdasarkan sumber bukan terpusat pada pengajar, dan bisa mengembang-kan pengetahuan yang dia terima dari sumber lainnya. Langkah-langkah model pembelajaran Cooperative Script (Miftahul, 2014), sebagai berikut.

1. "Guru membagi siswa ke dalam kelompok secara berapsangan.

2. Guru membagi wacana/materi untuk dibaca dan dibuat ringkasannya.

3. Guru dan siswa menetapkan siapa yang pertama berperan sebagai pembicara dan siapa yang berperan sebagai pendengar.

4. Pembicara membacakan ringkasannya selengkap mungkin dengan mema-sukkan ide-ide pokok ke dalam ringkasannya. Selama proses pemba-caan, siswa-siswa lain harus menyimak/ menun-jukkan ide-ide pokok yang kurang lengkap dan membantu mengingat dan menghafal ide-ide pokok dengan menghubungkannya dengan materi sebelumnya atau dengan materi lainnya.

5. Siswa bertukar peran, yang semula sebagai pembicara ditukar menjadi pendengar dan sebaliknya.

6. Guru dan siswa melakukan kembali kegiatan seperti di atas.

7. Guru dan siswa bersama-sama membuat kesimpu-lan materi pelajaran.

8. Penutup."

\section{B. Metode Penelitian}

Metode penelitian merupa-kan suatu cara atau langkah dalam mengumpulkan, mengor-ganisir, menganalisis, serta menginterpretasikan data. Penulis harus menentukan metode yang akan 
Didaktik : Jurnal IImiah PGSD STKIP Subang, ISSN Cetak : 2477-5673 ISSN Online : 2614-722X Volume V Nomor 2, Desember 2019

digunakan sebelum melakukan penelitian. Sugiyono (2017, hlm. 2) mengatakan "Metode penelitian pada dasarnya merupakan cara ilmiah untuk mendapatkan data dengan tujuan dan kegunaan tertentu." Maksudnya, dalam penelitian kita harus memperhatikan hal-hal secara ilmiah seperti cara pengumpulan data berdasarkan kegunaan dan tujuannya. Dalam penelitian ilmiah metode penelitian dapat dikatakan sebagai sebuah strategi, sehingga sebuah penelitian memerlukan metode penelitian untuk mencapai suatu keberhasilan.

Penulis menggunakan metode penelitian eksperimen. Desain yang digunakan dalam penelitian ini adalah pretest-posttest control group design. Desain metode penelitian ini dipilih karena terdapat kelompok kelas kontrol dan kelas eksperimen yang dipilih secara random. Setelah itu, kelas kontrol dan kelas eksperimen diberikan prates untuk menguji pengetahuan awal dan pascates untuk menguji pengetahuan akhir setelah diberi perlakuan.

Menurut Sugiyono (2015, hlm. 90), "Populasi adalah wilayah generalisasi yang terdiri atas obyek atau subyek yang mempunyai kualitas dan karakteristik tertentu yang ditetapkan oleh peneliti untuk dipelajari dan kemudian ditarik kesimpulannya." Populasi dalam penelitian ini adalah mahasiswa Program Studi Pendidikan Bahasa dan Sastra Indonesia FKIP Unpas. Sedangkan sampel menurut Sugiyono (2015, hlm. 91) adalah "bagian atau jumlah dan karakteritik yang dimiliki oleh populasi tersebut. Bila populasi besar, dan peneliti tidak mungkin mempelajari semua yang ada pada populasi, missal karena keterbatan dana, tenaga dan waktu, maka peneliti akan mengambil sampel dari populasi itu. Apa yang dipelajari dari sampel itu, kesimpulannya akan diberlakukan untuk populasi. Untuk itu sampel yang diambil dari populasi harus betul-betul representatif." Sampel dalam penelitian ini adalah mahasiswa semseter I Program Studi Pendidikan Bahasa dan Sastra Indonesia FKIP Unpas.

Teknik pengumpulan data pada penelitian ini adalah melalui teknik tes dengan instrumen tes sebagai alat yang digunakan untuk mengetahui kemampuan keterampilan menyimak maha-siswa. Teknik analisis data yang dilakukan dengan uji statistik 
Didaktik : Jurnal IImiah PGSD STKIP Subang, ISSN Cetak : 2477-5673 ISSN Online : 2614-722X Volume V Nomor 2, Desember 2019

dengan menggunakan aplikasi SPSS

25.

\section{Hasil dan Pembahasan}

Berdasarkan penelitian yang sudah dilakukan, diperoleh hasil tes menyimak dengan materi faktor

Tabel 1. Tabel Tes Kemampuan Keterampilan Menyimak

\begin{tabular}{|c|c|c|c|c|c|}
\hline \multirow{2}{*}{ No. } & Sub-jek & \multicolumn{2}{|c|}{ Kelas Kontrol } & \multicolumn{2}{c|}{ Kelas Eksperimen } \\
\cline { 3 - 6 } & Penelitian & Pra tes & Pascates & Prates & Pascates \\
\hline 1 & S1 & 45 & 55 & 40 & 90 \\
\hline 2 & S2 & 40 & 45 & 30 & 90 \\
\hline 3 & S3 & 35 & 45 & 60 & 90 \\
\hline 4 & S4 & 40 & 50 & 50 & 70 \\
\hline 5 & S5 & 55 & 75 & 55 & 80 \\
\hline 6 & S6 & 65 & 70 & 50 & 70 \\
\hline 7 & S7 & 35 & 55 & 40 & 85 \\
\hline 8 & S8 & 50 & 75 & 40 & 65 \\
\hline 9 & S9 & 35 & 55 & 25 & 60 \\
\hline 10 & S10 & 40 & 70 & 40 & 80 \\
\hline 11 & S11 & 60 & 70 & 50 & 75 \\
\hline 12 & S12 & 40 & 60 & 40 & 70 \\
\hline 13 & S13 & 40 & 70 & 35 & 85 \\
\hline 14 & S14 & 50 & 60 & 30 & 70 \\
\hline 15 & S15 & 50 & 55 & 50 & 75 \\
\hline 16 & S16 & 50 & 60 & 55 & 90 \\
\hline 17 & S17 & 25 & 40 & 20 & 80 \\
\hline 18 & S18 & 50 & 60 & 60 & 80 \\
\hline 19 & S19 & 65 & 60 & 50 & 35 \\
\hline 20 & S20 & 35 & 40 & 55 & 50 \\
\hline
\end{tabular}


Subjek penelitian dalam sampling. Berdasarkan uji deskripsi penelitian ini berjumlah 20 mahasiswa yang dilakukan menggunakan aplikasi yang diambil secara random spss diperolehlah hasil berikut.

Tabel 2

Uji Normalitas Data Kelas Eksperimen

Tests of Normality

\begin{tabular}{|c|c|c|c|c|c|c|c|}
\hline & \multicolumn{4}{|c|}{$\begin{array}{l}\text { Kolmogorov- } \\
\text { Smirnova }\end{array}$} & \multicolumn{3}{|c|}{ Shapiro-Wilk } \\
\hline & $\begin{array}{l}\mathrm{Te} \\
\mathrm{S}\end{array}$ & $\begin{array}{c}\text { Sta } \\
\text { tisti } \\
\text { C }\end{array}$ & Df & $\begin{array}{c}\text { Sig } \\
\text {. }\end{array}$ & $\begin{array}{l}\text { St } \\
\text { ati } \\
\text { stic }\end{array}$ & df & Sig \\
\hline Kelas_ & Pra & .18 & 20 & .06 & .95 & 20 & .36 \\
\hline Eksperi & tes & 7 & & 4 & 0 & & 8 \\
\hline men & $\begin{array}{l}\mathrm{Pa} \\
\text { sca } \\
\text { tes }\end{array}$ & $\begin{array}{r}.15 \\
1\end{array}$ & 20 & $\begin{array}{r}.20 \\
0^{*}\end{array}$ & $\begin{array}{r}.92 \\
3\end{array}$ & 20 & $\begin{array}{r}.11 \\
1\end{array}$ \\
\hline
\end{tabular}

${ }^{*}$. This is a lower bound of the true

significance.

a. Lilliefors Significance Correction

Berdasarkan tabel di atas, Kolmogorov-Smirnov menunjukkan informasi yang disampaikan adalah nilai signifikan 0,200 . Dari hasil uji mengenai uji normalitas data nilai normalitas data tersebut, tahap tes prates dan pascates dari kelas prates dan pascates berdasarkan uji eksperimen. Pada tahap tes prates, uji Kolmogorov-Smirnov menunjukkan normalitas data menggunakan uji nilai signifikan lebih dari (>) 0,05. Kolmogorov-Smirnov menunjukkan Maka dari itu, dapat disimpulkan nilai signifikan 0,368 . Sedangkan bahwa data nilai kelas eksperimen pada tahap tes pascates, uji memiliki data yang normal.

normalitas data menggunakan uji 


\section{Tabel 3}

\section{Uji Normalitas Data Kelas Kontrol}

\section{Tests of Normality}

Kolmogorov-Smirnov ${ }^{\mathrm{a}}$

\section{Shapiro-Wilk}

\begin{tabular}{|c|c|c|c|c|c|c|c|}
\hline & Tes & Statistic & $d f$ & Sig. & Statistic & $d f$ & Sig. \\
\hline Kelas & Prates & .188 & 20 & .062 & .941 & 20 & .252 \\
\hline $\begin{array}{l}\text { _Kon } \\
\text { trol }\end{array}$ & $\begin{array}{l}\text { Pascat } \\
\text { es }\end{array}$ & 154 & 20 & $.200^{*}$ & .933 & 20 & .180 \\
\hline
\end{tabular}

Berdasarkan tabel di atas, informasi yang disampaikan adalah mengenai uji normalitas data nilai prates dan pascates dari kelas kontrol. Pada tahap tes prates, uji normalitas data menggunakan uji KolmogorovSmirnov menunjukkan nilai signifikan 0,062 . Sedangkan, pada tahap tes pascates, uji normalitas data menggunakan uji KolmogorovSmirnov menunjukkan nilai signifikan 0,200. Dari hasil uji normalitas data

Tabel 4

Uji Homogenitas Data Test of Homogeneity of Variances

Levene Statistic df1 df2 Sig.

\begin{tabular}{|c|c|c|c|c|c|}
\hline & Test o & $\begin{array}{l}\text { Jji Ho } \\
\text { Homc }\end{array}$ & $\begin{array}{l}\text { bel } 4 \\
\text { yenitas } D \\
\text { neity of } V\end{array}$ & nces & \\
\hline & Levene Statistic & & df1 & df2 & Sig. \\
\hline$\overline{\mathrm{Pa}}$ & Based on Mean & .050 & 1 & 38 & .825 \\
\hline sca & Based on Median & .062 & 1 & 38 & .804 \\
\hline tes & $\begin{array}{l}\text { Based on Median } \\
\text { and with adjusted } \\
\text { df }\end{array}$ & .062 & 1 & 37.449 & .804 \\
\hline & $\begin{array}{l}\text { Based on } \\
\text { trimmed mean }\end{array}$ & .053 & 1 & 38 & .819 \\
\hline
\end{tabular}

tersebut, tahap tes prates dan pascates berdasarkan kolmogorovsmirnov menunjukkan nilai signifikan lebih dari $(>)$ 0,05. Maka dari itu, dapat disimpulkan bahwa data nilai kelas kontrol memiliki data yang normal.

Selain uji normalitas data, uji prasyarat data juga menguji homogenitas data. Uji homogenitas data dilakukan untuk mengetahui data hasil homogen atau tidak. 
Didaktik : Jurnal IImiah PGSD STKIP Subang, ISSN Cetak : 2477-5673 ISSN Online : 2614-722X Volume V Nomor 2, Desember 2019

$\begin{array}{lrrr}\text { Pada tabel } & \text { di } & \text { atas } & \text { menunjukkan nilai signifikan 0,825 } \\ \text { menginformasikan tentang } & \text { uji } & \begin{array}{l}\text { lebih dari }(>) \\ \text { 0,05. Maka dari itu, dapat }\end{array} \\ \text { homogenitas nilai pascates kelas } & \begin{array}{l}\text { disimpulkan bahwa data tersebut } \\ \text { homogen. } \\ \text { eksperimen dan kelas kontrol. Hasil uji }\end{array} & \text { Selanjutnya akan dilanjut-kan } \\ \text { homogenitas tersebut menunjukkan } & \text { dengan uji hipotesis untuk menguji } \\ \text { nilai signifikan 0,825 berdasarkan nilai } & \text { apakah Ha atau Ho diterima ataupun } \\ \text { rata-ratanya (based on mean). Dari } & \text { ditolak. }\end{array}$

Tabel 5

Uji Hipotesis Peningkatan Prestasi Menyimak

Paired Samples Test

Paired Differences

\begin{tabular}{|c|c|c|c|c|c|c|c|c|}
\hline & & ancu & 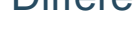 & 11000 & & & & \\
\hline & & & & & $5 \%$ & & & \\
\hline & & & & Confi & dence & & & \\
\hline & & & Std. & Interva & of the & & & Sig. \\
\hline & & Std. & Error & Diffe & rence & & & $(2-$ \\
\hline & Mean & Deviation & Mean & Lower & Upper & $\mathrm{t}$ & df & tailed) \\
\hline Pair Prates - & - & 14.186 & 3.172 & & - & & 19 & .000 \\
\hline 1 Pascates & 34.750 & & & 41.389 & 28.111 & 10.955 & & \\
\hline
\end{tabular}

Tabel di atas menunjukkan nilai

Pendidikan Bahasa dan Sastra probabilitas atau signifikannya (sig. 2 Indonesia FKIP Unpas dalam tailed) kurang dari (<) 0,05 yaitu 0,000. perkuliahan Teori dan Praktik Maka dari itu, dapat diartikan bahwa Pembelajran Menyimak terdapat peningkatan hasil belajar menggunakan model pembelajaran mahasiswa semseter I Program Studi Cooperative Script. 


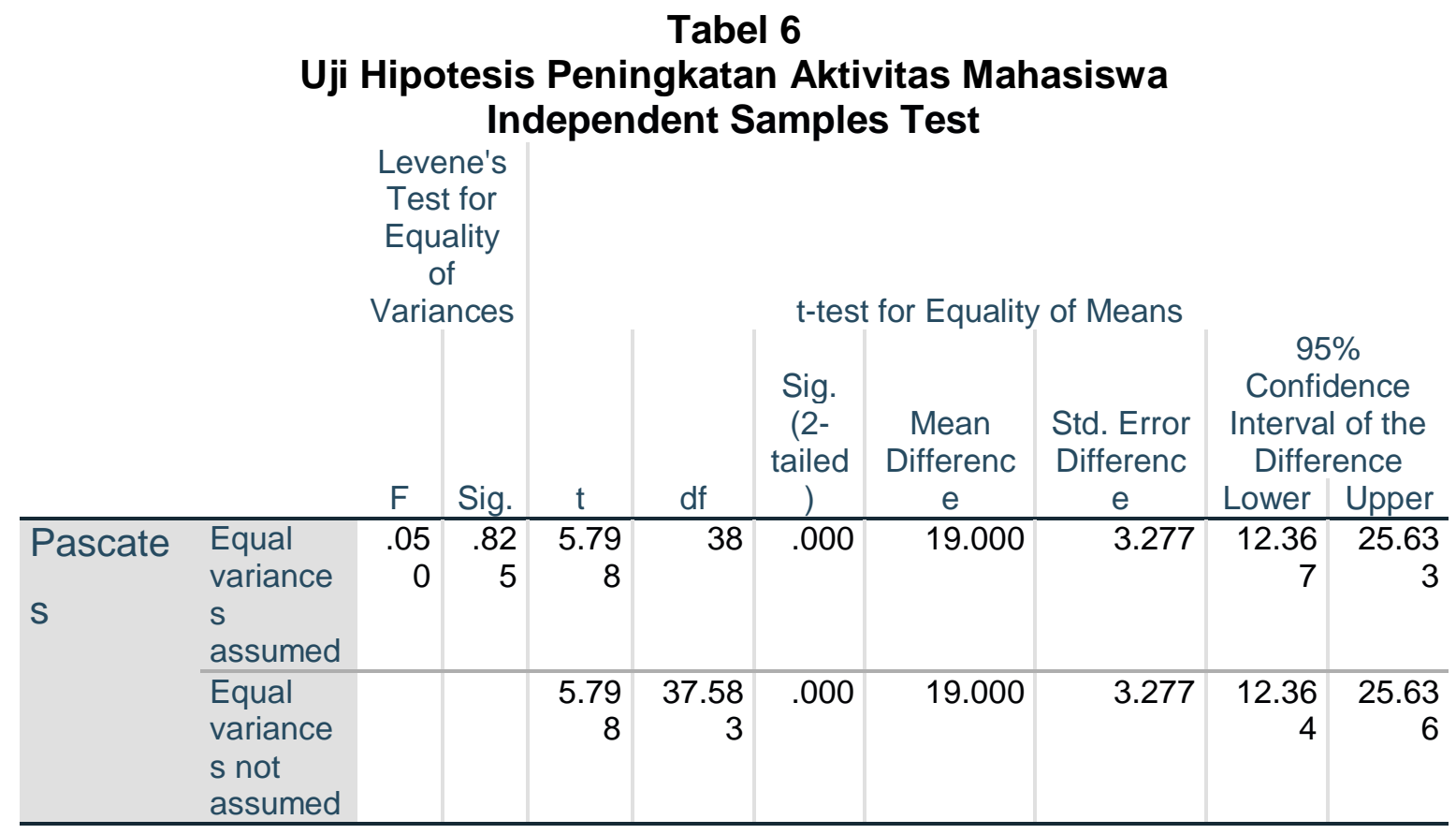

Tabel di atas menunjukkan nilai dan Sastra Indonesia FKIP Unpas probabilitas atau signifikannya (sig. 2 meningkat dalam perkuliahan Teori tailed) kurang dari (<) 0,05 yaitu 0,000. dan Praktik Pembelajran Menyimak Maka dari itu, dapat diartikan bahwa aktivitas mahasiswa semseter I menggunakan model pembe-lajaran Cooperative Script.

Program Studi Pendidikan Bahasa

Tabel 7

Uji Hipotesis Peningkatan Keterampilan Berbicara Mahasiswa Independent Samples Test

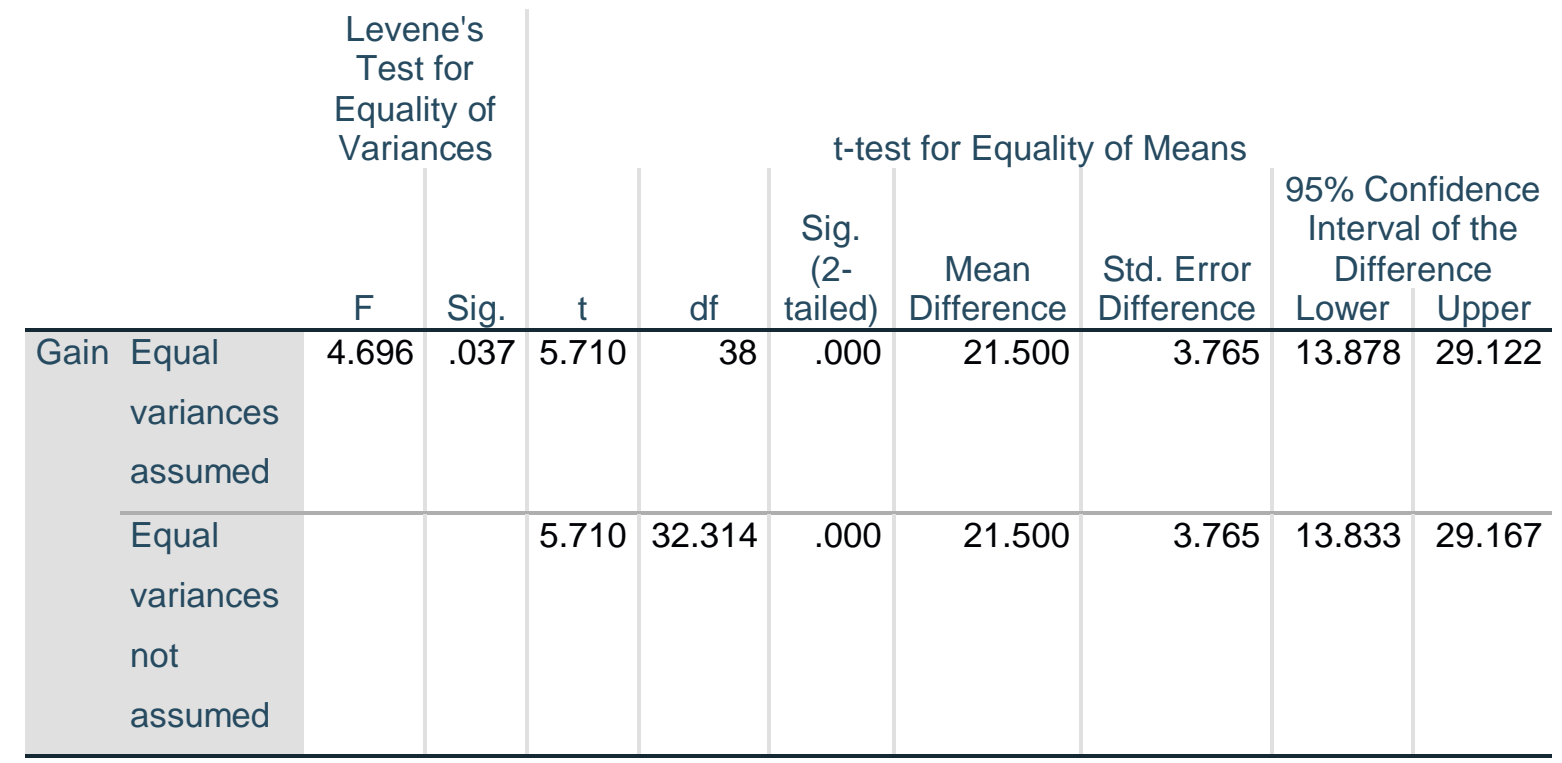


Tabel di atas menunjukkan nilai probabilitas atau signifikannya (sig. 2 tailed) kurang dari (<) 0,05 yaitu 0,000. Maka dari itu, dapat diartikan keterampilan berbi-cara mahasiswa semseter I Program Studi Pendidikan Bahasa dan Sastra Indonesia FKIP Unpas meningkat dalam perkuliahan Teori dan Praktik Pembelajran Menyimak meng-gunakan model pembelajaran Cooperative Script.

\section{Kesimpulan}

Berdasarkan hasil penelitian yang penulis lakukan terdapat beberapa kesimpulan sebagai berikut.

1. Terdapat peningkatan hasil belajar mahasiswa semseter I Program Studi Pendidikan Bahasa dan Sastra Indonesia FKIP Unpas dalam perkuliahan Teori dan Praktik Pembelajran Menyimak menggunakan model pembelajaran Cooperative Script. Hal tersebut dibuktikan t-test nilai signifikan (sig. 2 tailed) 0,000 kurang dari (<) 0,05.

2. Terdapat peningkatan aktivitas mahasiswa semseter I Program Studi Pendidikan Bahasa dan Sastra Indonesia FKIP Unpas dalam perkuliahan Teori dan Praktik Pembelajran Menyimak menggunakan model pembe- lajaran Cooperative Script. Hal tersebut dibuktikan t-test nilai signifikan (sig. 2 tailed) 0,000 kurang dari $(<) 0,05$. Selain hal tersebut, aktivitas pembelajaran mahasis-wa dalam perkuliahan semakin tinggi, dikarenakan semua mahasiswa mempunyai tang-gung jawab menyampaikan materi yang dipelajari

3. Terdapat peningkatan keterampilan berbicara mahasiswa semseter I Program Studi Pendidikan Bahasa dan Sastra Indonesia FKIP Unpas dalam perkuliahan Teori dan Praktik Pembelajran Menyimak menggunakan model pembelajaran Cooperative Script. Hal tersebut dibuktikan t-test nilai signifikan (sig. 2 tailed) 0,000 kurang dari (<) 0,05. Selain hal tersebut, kemampuan berkomunikasi lisan mahasiswa sangat baik, dikarenakan mahasiswa diarah-kan untuk mampu memahami dan menuangkan ke dalam bentuk tulisan yang kemudian disampaikan dalam presentasi secara logis dan sistematis. 


\section{DAFTAR PUSTAKA}

Adi, F. M., Phang, F. A., \& Yusof, K. M. (2012). Student Perceptions Change in a Chemical Engineering Class Using Cooperative Problem Based Learning. Procedia-Social and Behavioral Sciences, 627-635.

Natalina, M., Nursal, \& Srini. (2013). Penerapan Model Pembelajaran Cooperative Script Untuk Meningkatkan Aktivitas dan Hasil Belajar Biologi Siswa Kelas VII SMP Negeri 14 Pekanbaru. Jurnal Biogenesis, 44-51.

Miftahul, H. (2014). Model-model Pengajaran dan Pembelajaran: Isu-isu Metodis dan Paradigmatisi. Yogyakarta: Pustaka Pelajar.

Sugiyono. 2015. Metode Penelitian Kuantitatif Kualitatif dan R\&D. Bandung: Alfabeta.

Susiloyoga, J. (2016). Upaya Meningkatkan Kemampuan Menentukan Peluang Suatu Kejadian dengan Model Pembelajaran Kooperative Script pada Siswa Kelas IX-IPA 3 SMA Negeri 2 Madiun. Jurnal IImiah Edukasi Matematika, 3962.

Tarigan, Henry Guntur. 2008. Menyimak Sebagai Suatu Keterampilan Berbahasa. Bandung: Angkasa. 